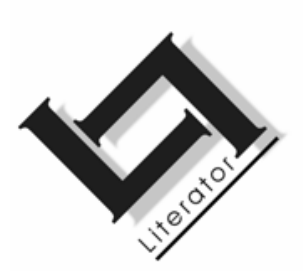

\title{
Mediadekking in die Suid-Afrikaanse gedrukte media oor taalverwante onderwerpe, in besonder taalregte en taalbeleidskwessies
}

\author{
Elbie Truter \\ Eenheid vir Taalbestuur \\ Universiteit van die Vrystaat \\ BLOEMFONTEIN \\ E-pos: TruterE.HUM@mail.uovs.ac.za
}

\begin{abstract}
Coverage of issues related to language, in particular language rights and language policy, in the South African print media

The print media are both important and reliable barometers for determining the feelings and attitudes of the reading public. This information, compiled in an annual report to PanSALB, may assist in making various groups aware of their language rights and could help to cultivate a proactive culture of language rights. This, in turn, could contribute towards the transformation of our society. It could also serve as deterrent to linguistic discrimination. In order to determine the validity of the assumptions represented in the print media, language issue coverage in the print media is compared to official language rights complaints lodged with PanSALB. The government might well avoid conflict by taking cognisance of language problems and ensuring that constitutional rights are upheld before problems arise.
\end{abstract}

\section{Opsomming}

Mediadekking in die Suid-Afrikaanse gedrukte media oor taalverwante onderwerpe, in besonder taalregte en taalbeleidskwessies

Die gedrukte media is 'n belangrike en betroubare barometer om die gesindhede en gevoelens van die leserspubliek te peil. Sodanige inligting, vervat in 'n jaarlikse verslag aan Pansat, kan 
meehelp om die bewustheid onder die gewone publiek rondom taalregte en taalregtekwessies te verhoog, wat met die proaktiewe gesindheid transformasie van die gemeenskap kan bevorder. Terselfdertyd kan dit dien as teenvoeter vir taaldiskriminasie. Ten einde die geldigheid van die gevolgtrekkings vas te stel, is vergelykings getref met die amptelike taalregteklagtes wat aan die amptelike taaliggaam, Pansat, gerig is. Dit sal die regering loon om betyds kennis te neem van probleme op taalgebied ten einde konflik te vermy, deur toe te sien dat grondwetlike regte nagekom word.

\section{Inleiding}

In 'n analise van die struktuur van die amptelike taalwetgewing (artikel 6 van Wet 108 van 1996), betoog Du Plessis en Pretorius (2000:505-506) dat die praktiese toepassing van die taalklousule hom leen tot uiteenlopende interpretasies. Daarby bestaan daar twyfel by hulle of die bewindhebbers die beginsel van veeltaligheid met die nodige erns bejeën. Hulle merk die volgende op:

Generally speaking, it is probably correct to state that the evolving pattern of official language policy in South Africa reveals a trend towards English, thus in effect towards official monolingualism (Du Plessis \& Pretorius, 2000:506).

'n Pan-Suid-Afrikaanse Taalraad (Pansat) is in die lewe geroep (Wet 59 van 1995) om die wetlike toepassing van die amptelike taalbeleid te monitor. Pansat het die implementering van verskeie fokusareas goedgekeur. Onder die fokusarea is die Taalraad se mandaat om

ondersoeke na beweerde oortredings van taalregte, -beleids of -praktyk te fasiliteer. [...] Die Raad moedig praktyk en beleid aan wat daartoe sal bydra dat Suid-Afrikaners bevry word van alle vorme van taaldiskriminasie (Pansat, 2002:176).

Hiermee saam poog Pansat om "alle taalgroepe bewus [te] maak van hul taalregte" (Pansat, 2002:177).

Ten einde voldoende inligting oor taalregte en taalkwessies in SuidAfrika te verkry, het Pansat die Eenheid vir Taalfasilitering en -bemagtiging (ETFB) aan die Universiteit van die Vrystaat (UV) (tans Eenheid vir Taalbestuur) opdrag gegee om behulpsaam te wees met die daarstelling van 'n South African Language Rights Monitor (SALRM). Die oogmerk van dié jaarlikse verslag is om die gegewens oor taalregteklagtes en taalkwessies in die SuidAfrikaanse gedrukte media saam te stel, op die formaat van die Kanadese model, die Canadian Commissioner of Official Languages 
(cf. Annual Report, 2002). Spesifieke oogmerke van die SALRM $(2004 ; 2005)$ is onder meer die volgende:

- voorsiening van 'n kritiese oorsig van mediadekking oor taalkwessies;

- voorsiening van inligting van en 'n kritiese analise van taalregteklagtes en bevindinge in Suid-Afrika.

Omdat die status van die onderskeie tale in Suid-Afrika 'n belangrike besprekingspunt geword het, veral na 1994, het sake omtrent die nakoming van die grondwetlike taalregte wye publisiteit in die gedrukte media ontvang. Kommentaar in die pers is as data gebruik vir die inhoudsontleding van die taaldebat.

In die volgende afdeling word 'n inhoudsontleding van taalregteklagtes in die Suid-Afrikaanse gedrukte media, vir die periode 1 Januarie 2003 tot 31 Desember 2003 (die tweede jaar van die SALRM-projek), gedoen. In die derde afdeling word 'n vergelyking getref tussen die taalregteklagtes in die gedrukte media en dié wat by Pansat geregistreer is. Die doelwit met die ondersoek is om aan te toon watter taalinsidente aanleiding tot ontevredenheid onder sekere taalgroepe gegee het sodat die regering pro-aktief kan optree om potensiële taalkonflikte te ontlont.

\section{Rekenskap van die empiriese ondersoek}

In hierdie afdeling word dekking in die gedrukte media van taalkwessies in die algemeen en van taalregtekwessies in die besonder vir die jaar 2003 ondersoek. In die eerste onderafdeling word ' $n$ teoretiese motivering vir die ondersoek gegee, en in die volgende onderafdeling word die metodologie uiteengesit. In die daaropvolgende onderafdelings word taalverwante data, taalregteklagtes en taalregteklaers bespreek.

\subsection{Teoretiese motivering vir die ondersoek}

In 'n ondersoek na taalbeleid in die gemeenskap kom Tollefson tot die slotsom dat "a commitment to democracy requires a commitment to struggle for language rights" (Tollefson, 1991:211). In haar studie Heroes, rebels, communities and states in language rights activism and litigation, beskou Martel taalregte-aktivisme as 'n essensiële komponent, selfs 'n onvermydelike proses in 'n poging om die gemeenskap te demokratiseer. Sy beskryf taalregte-aktivisme as 'n regte-georiënteerde proses waardeur druk geplaas kan word om 
sosio-politieke praktyke en strukture te verander (Martel, 1999:4748).

Dit is belangrik dat 'n onderskeiding tussen taalaktivisme en taalregte-aktivisme getref word. Vir sowel Steyn (1980:74) as Du Plessis (1987) handel taalaktivisme selde slegs oor taal per se, maar kan dit eerder dien as 'n tipe politieke drukgroep. Taalaktivisme word meestal ondersoek binne die konteks van taalregte. Coulombe (1993:140) onderskei taalaktivisme van taalregte-aktivisme in dié opsig dat eersgenoemde rolspelers wil oortuig om sosiale praktyke, ideologieë en strukture tot stand te bring wat die handhawing en ontwikkeling van taalgemeenskappe verander. Ook Martel beskou taalregte-aktivisme as 'n

manifestation of a rising consciousness, and rejection, of conditions of submission/oppression/control/domination/authority/ centralization/monopoly. It can be a challenge to sociopolitical structures that reproduce non-equitable power relations (Martel, 1999:49).

Martel (1999:47) onderskei ses instrumente van taalregte-aktivisme, naamlik litigasie, die skepping van drukgroepe (lobbying), navorsing, gemeenskapsmobilisering, mediadekking, en die uiterste vorm, naamlik geweld, soos, onder andere, in Noord-lerland voorkom (Jenkins, 1991). Du Plessis (2004:170) onderskei 'n sewende instrument van taalregte-aktivisme, naamlik die indien van 'n taalregteklagte by ' $n$ amptelike instansie wat vir dié doel in die lewe geroep is, byvoorbeeld Pansat in Suid-Afrika.

Terwyl die gebruik van die gedrukte media nie dieselfde kragtige instrument as byvoorbeeld litigasie is nie - laasgenoemde "remained a final strategy" volgens Martel (1999:65) - is die gebruik van die gedrukte media, tesame met die ander instrumente, egter deur Martel (1999) en Du Plessis (2004) onderskei as 'n effektiewe instrument om die gemeenskap te mobiliseer. Meningsvormers en belangegroepe kan die gedrukte media aanwend om lesers subtiel en daadwerklik te oorreed om aktief deel te neem ten behoewe van 'n saak, byvoorbeeld die bevordering en beskerming van Afrikaans. Resente mediaopskrifte in die Afrikaanse pers, "Ons soek aksie vir Afrikaans" (Du Toit, 2005) en "Protes moet sterker. Dis gesond dat Afrikaners betoog" (Steyn, 2005:10), kan allermins beskou word as voorbeelde van minder subtiele beïnvloeding, maar doen eerder 'n oproep tot aktivistiese optrede.

Politieke partye en belangegroepe maak van die gedrukte media gebruik om regeringsbeleid te probeer beïnvloed. As gevolg van die 
oorheersende posisie van die African National Congress (ANC) en sy alliansievennote, die Congress of South African Trade Unions (Cosatu) en die Suid-Afrikaanse Kommuniste Party (SAKP), is die invloed wat die gedrukte media op regeringsbeleid uitoefen, beperk tot besonderhede van beleidsadminstrasie en die implementering daarvan (Booysen \& Erasmus, 1998:240).

Die gedrukte media kan verder 'n betekenisvolle bydrae maak tot die debat om die ideologiese oriëntasie van beleidmakers rondom taalkwessies te beïnvloed. Cobarrubias (1983:66; vgl. ook Kamwangamalu, 2003:175) onderskei twee hoof-ideologiese oriëntasies, naamlik internasionalisering en vernakularisering. Vernakularisering behels die herstel en/of uitbreiding van 'n inheemse taal tot amptelike taal, terwyl internasionalisme die voorkeur aan 'n nieinheemse internasionale taal soos Engels, Frans, ensovoorts as ampstaal en onderrigtaal op skool verleen. Internasionalisme is wesenlik ' $n$ vorm van assimilasionisme (Cobarrubias, 1983:66). Die onderskrywing van internasionalisering lei tot taalhiërargie, linguisisme of linguistiese rassisme, soos Kamwangamalu (2003: $177)$ daarna verwys. Hiervolgens word die hulpbronne van minderheidsgroepe as 'n belemmering beskou (Strydom \& Pretorius, 2000:113). In die geval van Suid-Afrika beteken dit dat die voormalige koloniale taal, Engels, voorrang geniet en dat al die ander tale wat amptelike status in die Grondwet geniet, gemarginaliseer word. Die wenslikheid van vernakularisering in die Suid-Afrikaanse konteks, en die bydrae van die media in hierdie verband, spreek vanself. Die gedrukte media kan in hierdie verband 'n wesenlike bydrae lewer om die wenslikheid van vernakulisering in die Suid-Afrikaanse konteks meer algemeen bekend te stel.

Die rede waarom die media vernakularisering behoort te bevorder, en nie internasionalisme nie, is omdat internasionalisme die regte van sprekers van ander tale aantas. Internasionalisme het normaalweg die absorbering van een taalgroep(e) deur 'n ander taalgroep(e) tot gevolg, waardeur die geassimileerde groep(e) nie net hulle taal nie, maar ook hulle identiteit verloor, en met die nuwe taal die identiteit van ander taalgroep oorneem (Lubbe, 2003:121).

Om die amptelike indringing van Engels op die terreine van die ander tien amptelike tale te verhoed/beperk, is die gedrukte media die beste toegerus om die morele waarde so te verhoog, dat diegene met gevestigde belange in die status quo geen politieke gronde kan vind om dit teen te staan nie. 'n Voorbeeld is die invloed wat die media uitgeoefen het om die algemene leserspubliek bewus 
te maak van die bedreiging van fauna en flora deur omgewingskwessies en -aktiwiteite uit te lig.

Heelwat navorsing oor die rol van die gedrukte media in taalkwessies het reeds die lig gesien. Een van die omvangrykste is Steyn (1995) wat die gesindhede teenoor Afrikaans, soos weerspieël in die pers vanaf 2 Februarie 1990 tot 27 April 1994, nagegaan het. Kwessies soos die amptelike taaldebat, die taal van onderrig en wetenskap, en taalsake in die openbare uitsaaiwese kom onder die loep.

In die kader van Kritiese Taalkunde (KT) het verskeie studies die lig gesien waarin aangetoon is hoe ideologie deur die gebruik van taal op 'n subtiele wyse deur die media gepropageer word. Thetela (2001) is byvoorbeeld, 'n ondersoek na mediaberigte van die militêre ingryping deur die Suid-Afrikaanse Weermag (SAW) in 1998 in Lesotho.

Inhoudsanalises en kwantitatiewe ontledings is verdere metodes om die rol van die media te ondersoek. Inhoudsontleding kan sowel kwalitatief as kwantitatief van aard wees. Lubbe en Du Plessis (2001) doen 'n inhoudsanalise van die debat in die gedrukte media van die interpretasie van die amptelike taalbeginsels van die Tussentydse Grondwet. Truter (2002) weer doen 'n kwantitatiewe ontleding van die reaksies van Afrikaanssprekendes op die veranderings in die taalbeleid en die vermeende agterstelling van Afrikaans in die Vrystaat vir die periode 1994 tot 1998, terwyl Truter (2003) die reaksies in mediaberiggewing van moedertaalsprekers van Afrikaans op taalbeleidsveranderings van die South African Broadcasting Corporation (SABC) vir die periode 1994 tot 1996 interpreteer. Truter en Lubbe (2005) doen 'n ontleding aan die hand van taalregteklagtes van minderheidsgroepe oor die toepassing van die taalbeleid in Suid-Afrika. Nog kwantitatiewe taalanalises van aspekte soos behandel in die Suid-Afrikaanse gedrukte media, is onder andere gedoen deur Fourie (1994), Du Plessis (2004), Van Rensburg et al. (s.a.), Schlemmer en Giliomee (2001), terwyl D'Alessio en Allen (2000) 'n kwantitatiewe ondersoek na mediavooroordeel in die aanloop tot die presidensiële verkiesings in die Verenigde State van Amerika (VSA) na 1948, uitgevoer het.

\subsection{Metodologie}

Bronne vir die ontleding van taalverwante onderwerpe wat in die gedrukte media vir die periode 1 Januarie 2003 tot 31 Desember 
2003 verskyn het, is van knipsels van SA Media aan die Universiteit van die Vrystaat (UV) verkry.

SA Media ontsluit die belangrikste hoofstroomkoerante,-tydskrifte en -joernale. Vir 2003 is beriggewing van 73 publikasies ontvang. Omdat alle streekskoerante en sommige van die koerante in Afrikatale nie geëkserpeer word nie, word daar derhalwe nie op volledigheid aanspraak gemaak nie; hiervan is $49(67,1 \%)$ Engels, $17(23,3 \%)$ Afrikaans en $7(9,6 \%)$ tweetalig. Die publikasieverhouding van Engelse tot Afrikaanse publikasies is 2,9:1. Vir die doeleindes van hierdie artikel is gegewens van SALRM (2004), die eerste jaar van dié projek, vir vergelykende doeleindes gebruik.

Om relevante mediaknipsels te trek, is die grootste aantal moontlike trefwoorde rondom die verskillende kategorieë soos deur SA Media gekategoriseer, gebruik. Altesaam 2694 rekords is geëkserpeer. Die rekords sluit die volgende in: berigte, redaksionele kommentaar, briewe van die leserspubliek, rubrieke, artikels (bydrae van kundiges), resensies, spotprente en advertensies. Die meerderheid rekords is uit koerante ontsluit. Die verhouding van koerante tot tydskrifte is $96,7 \%$ (2 630) tot 2,3\% (64).

\subsection{Bespreking van taalverwante data}

Die taalverwante onderwerpe en die verspreiding tussen die Afrikaanse, Engelse en tweetalige media word in Tabel 1 hierna weergegee.

Die rede waarom die totaal van 4223 veel hoër is as die 2694 rekords, is omdat een rekord meer as een taalverwante verwysing kan bevat: een mediarekord kan byvoorbeeld verwys na 'n taalregteklagte, die regeringsreaksie daarop asook dié van Pansat. Dit is veral die geval met pleknaam- en naamsveranderinge. Interessant is dat plekname $(9,9 \%$ (416)) groter mediadekking geniet het as taalregte per se $(3,2 \%(133))$, waarskynlik omdat dit groter ruimte laat vir drukgroepe, soos geblyk het uit die voorgestelde naamsverandering van Pretoria na Tshwane.

Bykans 'n kwart (32,9\%) van die dokumente verwys na resensies. Slegs resensies wat op taal betrekking het, is in berekening gebring, naamlik resensies van fiksie en nie-fiksie. Resensies van die skone en visuele kunste, argitektuur, fotografie, films, televisieprogramme en dansteater is buite rekening gelaat. 
Tabel 1: Konteks waarin taal vermeld word en die taalmedium van die gedrukte media

\begin{tabular}{|c|c|c|c|c|c|c|c|c|}
\hline \multirow[b]{2}{*}{ Kategorie } & \multicolumn{2}{|c|}{ Afrikaans } & \multicolumn{2}{|l|}{ Engels } & \multicolumn{2}{|c|}{ Tweetalig } & \multicolumn{2}{|l|}{ Totaal } \\
\hline & $\mathbf{N}$ & $\%$ & $\mathbf{N}$ & $\%$ & $\mathbf{N}$ & $\%$ & $\mathbf{N}$ & $\%$ \\
\hline Vermindering taalgebruik & 73 & 1,7 & 28 & 0,7 & 0 & 0,0 & 101 & 2,4 \\
\hline Vermeende skending taalregte & 186 & 4,4 & 76 & 1,8 & 0 & 0,0 & 262 & 6,2 \\
\hline Amptelike aankondigings & 35 & 0,8 & 31 & 0,7 & 0 & 0.0 & 66 & 1,6 \\
\hline Aktivisme & 42 & 1,0 & 32 & 0,8 & 1 & 0,0 & 75 & 1,8 \\
\hline CPPRCRLC* & 10 & 0,2 & 6 & 0,1 & 0 & 0,0 & 16 & 0,4 \\
\hline Bespreking & 229 & 5,4 & 83 & 2,0 & 0 & 0,0 & 312 & 7,4 \\
\hline Regeringsreaksie & 14 & 0,3 & 12 & 0,3 & 0 & 0,0 & 26 & 0,6 \\
\hline Positiewe taalbeplanning & 218 & 5,2 & 106 & 2,6 & 0 & 0,0 & 324 & 7,7 \\
\hline Taalnavrae & 1 & 0,0 & 2 & 0,1 & 0 & 0,0 & 3 & 0,1 \\
\hline Taalregte & 89 & 2,1 & 44 & 1,0 & 0 & 0,0 & 133 & 3,2 \\
\hline Taalregteklagteleggers & 346 & 8,2 & 214 & 5,1 & 1 & 0,0 & 561 & 13,3 \\
\hline Taalregteklagtes & 287 & 6,8 & 157 & 3,7 & 1 & 0,0 & 445 & 10,5 \\
\hline Nasionale Raad van Provinsies & 5 & 0,1 & 2 & 0,1 & 0 & 0,0 & 7 & 0,2 \\
\hline Huis van Tradisionele Leiers & 2 & 0,1 & 1 & 0,0 & 0 & 0,0 & 3 & 0,1 \\
\hline Pansat vermeld in media & 44 & 1,0 & 17 & 0,4 & 0 & 0,0 & 61 & 1,4 \\
\hline SA Menseregtekommissie & 3 & 0,1 & 5 & 0,1 & 0 & 0,0 & 8 & 0,2 \\
\hline Pleknaam- en naamsverandering & 179 & 4,2 & 237 & 5,6 & 0 & 0,0 & 416 & 9,9 \\
\hline Resensies & 597 & 14,1 & 791 & 18,7 & 2 & 0,1 & 1390 & 32,9 \\
\hline Ander & 2 & 0,1 & 12 & 0,3 & 0 & 0,0 & 14 & 0,3 \\
\hline Totaal & 2362 & 55,9 & 1856 & 44.0 & 5 & 0,1 & 4223 & 100,0 \\
\hline
\end{tabular}

(*Kommissie vir die Bevordering en Beskerming van Kulturele, Godsdienstige en Taalgemeenskappe)

Die ontleding van die gegewens het getoon dat pogings om die gebruik en funksies van 'n taal (tale) uit te bou, 'n relatief hoë insidensie, $7,7 \%$ (324), in mediaberiggewing geniet het. Hierdie gevalle van die bevordering en uitbouing van die funksies van 'n taal, soos aangetoon deur Hornberger (2006:29 e.v.) sluit taal- 
bewaring, verspreiding en modernisering in en kan oorkoepelend as 'n positiewe taalbeplanning gekarakteriseer word. Positiewe taalbeplanning kan deur individue, kulturele groepe, die besigheidsektor en regeringinstansies geïnisieer word. Die persepsie dat die regering deurgaans onverskillig staan teenoor pogings om minderheidstale te bevorder, moet heroorweeg word in die lig van mediaberiggewing waarin geblyk het dat bykans driekwart of $69,8 \%$ (226 van 324) berigte verwys na gevalle van positiewe taalbeplanning wat deur amptelike instansies geïnisieer is, en $30,2 \%$ (98 van 324) na gevalle deur nie-amptelike instansies. Amptelike pogings sluit inter alia voorstelle in om 'n nuwe taalbeleid in die Parlement in te stel, vertalings- en tolkingsdienste, asook 'n besluit om die belangrikste amptelike inligting in al elf amptelike tale te publiseer. In 7,1\% (23 van 324) van gevalle het positiewe taalbeplanning die uitbou van veeltaligheid behels, in besonder pogings deur statutêre liggame, byvoorbeeld Pansat, en sy subkomitees, die Nasionale Taalliggame (NTL) en die Nasionale Taaliggaam vir Afrikaans (NTLA) wat die inisiatiewe ten behoewe van Afrikaans koördineer.

In slegs twee subkategorieë, naamlik resensies en plekname en -veranderinge, is die beriggewing hoër in die Engelse media, wat hoofsaaklik aan die groter aantal Engelse koerante en tydskrifte toe te skryf is. Veral merkwaardig is die wyer mediadekking wat die verandering van plekname in die Engelse media geniet het, naamlik $57 \%$ (237 van 416) teenoor Afrikaans 43\% (179 van 416), as in ag geneem word dat die meerderheid naamsveranderinge geskied het ten koste van name wat uit historiese figure of plekke van die Afrikanergeskiedenis dateer. Die hoogste verwysing na plekname en -veranderinge was na stede/dorpe $(28 \%)$, gevolg deur tersiêre inrigtings $(21 \%)$, hoofsaaklik vanweë die samesmelting van technikons en universiteite, asook die verandering van straatname (8\%). Die provinsies waar die hoogste insidensie van beriggewing van pleknaamsveranderinge plaasgevind het, is Gauteng met $19,9 \%$ (33 van 416) - hoofsaaklik vanweë die voorgestelde verandering van Pretoria na Tshwane - en KwaZulu-Natal met 18,8\% (33 van 416) - hoofsaaklik as gevolg van verafrikanisering van voorheen verangliseerde Zoeloebenamings. Die hoë mediadekking wat veranderinge van plekname in Limpopo geniet het, verwys hoofsaaklik na benamings uit die Afrikanergeskiedenis, inter alia Louis Trichardt (Makhado), Pietersburg (Polokwane) en Nylstroom (Modimolle).

Die belang van taalregte en die suksesvolle oplossing van taalregtekwessies kan afgelei word uit die relatiewe wye dekking wat 
die gedrukte media hieraan verleen. Daar word 'n onderskeid getref tussen taalregteklagtes en taalregteklagteleggers.

\subsection{Bespreking van taalregteklagtes}

Klagtes oor die (vermeende) miskenning van taalregte van (sekere) minderheidsgroepe word konstant in die gedrukte media gelug. Die konsep taalreg sluit sowel individuele regte as groepregte in. Individuele regte verseker nie-diskriminasie en nie-inmenging in 'n individu se private terrein van taalaktiwiteit, terwyl groepregte as 'n positiewe reg beskou kan word, omdat die handhawing en uitbouing daarvan positiewe staatsinmenging vereis. 'n Onderskeiding word getref tussen taalregteklagtes en taalregteklagteleggers. 'n Taalregte-insident verwys na 'n voorval wat aanleiding gee tot die lug van ' $n$ klagte deur ' $n$ taalregteklagtelegger. Taalregteklagteleggers lug hulle ontevredenheid of misnoeë as individue of namens 'n instansie (wat onder andere 'n politieke party, 'n vakbond, 'n kultuurof statutêre liggaam, tersiêre of onderwysorganisasie kan insluit). Dit geskied per taalregteklagte (brief) in die gedrukte media of by 'n amptelike instansie (Pansat), en handel oor 'n onaanvaarbare, onbevredigende situasie op taalvlak. Die beskuldiging of taalregteklagte is gegrond op (vermeende) taalregteskendings deur hoofsaaklik amptelike instansies en kan onder andere afkomstig wees vanuit die sakesektor, vanaf die gedrukte media self, vanaf privaat persone, of minderheidsgroepe of sektore van die samelewing wat miskennning van taalregte ervaar.

Tabel 2 bevat besonderhede omtrent die tipe mediarekords van taalregteklagtes per taalgroep.

Die diskrepansie tussen hierdie totaal (400) en dié in Tabel 1, naamlik 445 , is as gevolg van die weglating van spotprente (15), advertensies (4) en amptelike taalregteklagtes gerig aan Pansat (26).

Soos uit Tabel 2 blyk, het berigte wat verband hou met rekords oor taalregteklagtes die oorgrote meerderheid uitgemaak, naamlik $49,0 \%$ (196), gevolg deur lesersbriewe aan die redakteur, naamlik $21,5 \%(86)$. Die relatiewe hoë prominensie wat die gedrukte media aan taalregtekwessies verleen, toon dat die media 'n dinamiese rol speel om die leserspubliek bewus te maak van hul taalregte. Die verskil van $29,0 \%$ tussen die totale aantal Afrikaanse en Engelse mediarekords is onder andere toe te skryf aan die tradisionele sterker aktivistiese rol wat die Afrikaanse pers in dié verband in die verlede gespeel het en nog steeds speel. In al die kategorieë het die 
Afrikaanse pers die groter oorwig gehad. Hierdie groter bewussyn van taalregtekwessies word veral bevestig deur die verskil van $6,4 \%$ in die redaksionele kommentaar tussen die Engelse en Afrikaanse koerantgroepe. Dié groter bewussyn word verder bevestig deur die feit dat 4,5\% meer lesersbriewe gerig is aan Afrikaanse koerante as aan Engelse koerante, en dat 3,7\% meer rubrieke, asook 1,4\% meer artikels in die Afrikaanse media verskyn het. Dit het gaandeweg tot hierdie taalgroep deurgedring, soos blyk uit voorgaande, dat hulle "voortaan vir hulself [...] sal moet intree" (Goosen, 2005:13). Dié beywering vir veeltaligheid is nie eksklusief op Afrikaans gerig nie, maar ook ten behoewe van die ander nege inheemse tale.

Tabel 2: Taalregteklagtes per tipe mediarekord en taalmedium

\begin{tabular}{|l|c|c|c|c|c|c|}
\hline \multirow{2}{*}{ Kategorie } & \multicolumn{2}{|c|}{ Afrikaans } & \multicolumn{2}{c|}{ Engels } & \multicolumn{2}{c|}{ Totaal } \\
\hline Tipe & $\mathbf{N}$ & $\mathbf{\%}$ & $\mathbf{N}$ & $\mathbf{\%}$ & $\mathbf{N}$ & $\%$ \\
\hline Berigte & 124 & 31,0 & 72 & 18,0 & 196 & 49,0 \\
\hline $\begin{array}{l}\text { Redaksionele } \\
\text { kommentaar }\end{array}$ & 37 & 9,3 & 12 & 2,9 & 49 & 12,2 \\
\hline Briewe & 52 & 13,0 & 34 & 8,5 & 86 & 21,5 \\
\hline Rubrieke & 34 & 8,5 & 19 & 4,8 & 53 & 13,3 \\
\hline Artikels & 11 & 2,7 & 5 & 1,3 & 16 & 4,0 \\
\hline Totaal & $\mathbf{2 5 8}$ & $\mathbf{6 4 , 5}$ & $\mathbf{1 4 2}$ & $\mathbf{3 5 , 5}$ & $\mathbf{4 0 0}$ & $\mathbf{1 0 0 , 0}$ \\
\hline
\end{tabular}

Die handelinge van die regering, in besonder dié van die uitvoerende gesag, het aanleiding gegee tot 'n groot aantal taalregteklagtes, soos blyk uit Tabel 3.

Die diskrepansie tussen die totale aantal taalregteklagtes in Tabel 1, naamlik 445 en die 841 in Tabel 3, is toe te skryf aan die feit dat een mediaberig meer as een verwysing na taalregteklagtes kan bevat. 
Tabel 3: Taalregteklagte per staatsdomein

\begin{tabular}{|l|r|r|}
\hline Staatsdomein & $\mathbf{N}$ & \% \\
\hline Wetgewend & 51 & 6,1 \\
\hline Juridies & 34 & 4,0 \\
\hline Uitvoerend & 756 & 89,9 \\
\hline Totaal & $\mathbf{8 4 1}$ & $\mathbf{1 0 0 , 0}$ \\
\hline
\end{tabular}

Die verspreiding van taalregteklagtes in die uitvoerende domein op die verskillende regeringsvlakke word in Tabel 4 uiteengesit.

Tabel 4: Uitvoerende domein: bronne van taalregteklagtes per taalmedium

\begin{tabular}{|l|c|c|c|c|c|c|}
\hline Kategorie & \multicolumn{2}{|c|}{ Afrikaans } & \multicolumn{2}{c|}{ Engels } & \multicolumn{2}{c|}{ Totaal } \\
\hline & $\mathbf{N}$ & $\mathbf{\%}$ & $\mathbf{N}$ & $\mathbf{\%}$ & $\mathbf{N}$ & $\%$ \\
\hline Eerstevlak & 208 & 27,5 & 173 & 22,9 & 381 & 50,4 \\
\hline Tweedevlak & 142 & 18,8 & 97 & 12,8 & 239 & 31,6 \\
\hline Derdevlak & 62 & 8,2 & 74 & 9,8 & 136 & 18,0 \\
\hline Totaal & $\mathbf{4 1 2}$ & $\mathbf{5 4 , 5}$ & $\mathbf{3 4 4}$ & $\mathbf{4 5 , 5}$ & $\mathbf{7 5 6}$ & $\mathbf{1 0 0 , 0}$ \\
\hline
\end{tabular}

Ten minste die helfte van die taalregteklagtes met betrekking tot die uitvoerende domein het sy oorsprong op eerstevlakregering, naamlik 50,4\% (381 van 756). Daar is 'n opmerklike verskil tussen die rapportering van taalregteklagtes op eerstevlakregering tussen die koerante van die taalgroepe - daar is $4,6 \%$ ten gunste van Afrikaanse koerante. Op tweedevlakregering is die rapportering van taalregteklagtes nóg meer beduidend: hier is die verskil $6,0 \%$ ten gunste van Afrikaanse koerante. Die Engelse koerante het slegs by derdevlakregering (munisipaliteite) 'n wyer mediadekking aan taalregteklagtes verleen: hier is die verskil $1,6 \%$ ten gunste van die Engelse koerante.

Op eerstevlak het die doen en late van die Departement van Onderwys aanleiding gegee tot die hoë rapportering van taalregteklagtes - 37,3\% (142 van 381 ) van die taalregte-insidente - 
gevolg deur die Departement van Kommunikasie met 20,7\% (79 van 381 ), wat hoofsaaklik verwys het na taalregteklagtes rondom die SABC. Klagtes teen departemente in die algemeen, sonder verwysing na 'n spesifieke departement, het eweneens 20,7\% (79 van 381) van die taalregteklagtes uitgemaak.

Van die totale aantal taalregteklagtes met betrekking tot tweedevlakregering, het meer as die helfte, naamlik 52,7\% (126 van $239)$, verwys na naamsveranderinge, en amper 'n derde $(30,1 \%$ (72)) na die verskillende Departemente van Onderwys. Dit het meestal gehandel oor pogings om enkelmedium Afrikaanse skole te verander in parallel-/dubbelmedium skole. Gerapporteerde taalregteklagtes het in Gauteng vir 'n vyfde (20,9\% (50 van 239)) van die taalregteklagtes aanleiding gegee, gevolg deur KwaZulu-Natal met $15,5 \%$ (37 van 239), en Limpopo met 12,9\% (31 van 239). Die meeste van die taalregteklagtes op derderegeringsvlak (80,2\% (109 van 136)), het in besonder verband gehou met die voorgestelde naamsverandering van Pretoria na Tshwane.

Die taalregteklagtes het hoofsaaklik gehandel oor die bevoordeling van Engels en die verontagsaming van veeltaligheid in die algemeen deur adminstratiewe handelinge van die regering. Veral in die onderwys het die hegemonie van Engels tot groot ontevredenheid gelei. Ander klagtes het betrekking gehad op die medium van onderrig, op die taal van die instelling, oor die verslagtaal en oor interne en eksterne kommunikasie van die adminstrasie.

\subsection{Bespreking van taalregteklagteleggers}

Die verspreiding van die tipe mediarekords rondom taalregteklagteleggers met die taalmedium word aangetoon in Tabel 5.

Soos in die geval van taalregteklagtes, het die Afrikaanse media weereens die grootste mediadekking aan taalregteklagteleggers in al vyf tipes mediarekords verleen: in totaal 'n verskil van $25,0 \%$ tussen Afrikaanse en Engelse mediaberiggewing. As die verskil van $9,1 \%$ in die beriggewing en $6,4 \%$ in redakteurskommentaar van die twee taalgroeperinge in ag geneem word, is die slotsom weereens dat, ten spyte daarvan dat net 17 publikasies in Afrikaans verskyn het (teenoor 49 Engels en 7 tweetalig), die Afrikaanse gedrukte media ' $n$ prominenter rol in die bewusmaking van taalverwante kwessies vervul. 
Tabel 5: Taalregteklagteleggers per tipe mediarekord en taalmedium

\begin{tabular}{|l|c|l|c|c|c|c|}
\hline \multicolumn{1}{|c|}{ Kategorie } & \multicolumn{2}{c|}{ Afrikaans } & \multicolumn{2}{c|}{ Engels } & \multicolumn{2}{c|}{ Totaal } \\
\hline Tipe & N & \% & N & $\%$ & N & $\%$ \\
\hline Berig & 125 & 29,3 & 86 & 20,2 & 211 & 49,5 \\
\hline $\begin{array}{l}\text { Redaksionele } \\
\text { kommentaar }\end{array}$ & 40 & 9,4 & 13 & 3,0 & 53 & 12,4 \\
\hline Briewe & 54 & 12,7 & 34 & 8,0 & 88 & 20,7 \\
\hline Rubrieke & 34 & 8,0 & 23 & 5,4 & 57 & 13,4 \\
\hline Artikels & 13 & 3,1 & 4 & 0,9 & 17 & 4,0 \\
\hline Totaal & $\mathbf{2 6 6}$ & $\mathbf{6 2 , 5}$ & $\mathbf{1 6 0}$ & $\mathbf{3 7 , 5}$ & $\mathbf{4 2 6}$ & $\mathbf{1 0 0 , 0}$ \\
\hline
\end{tabular}

Tabel 6 toon die verskillende tipes taalregteklagteleggers per taalmedium. Die diskrepansie tussen die totaal van die tipes mediaberiggewing (426 in Tabel 5) en Tabel 6, naamlik 561, is as gevolg van die moontlikheid dat een mediarekord na meer as een taalregteklagtelegger kan verwys. Die oorgrote meerderheid mediarekords was afkomstig van private persone wat taalregtebesware in die media gelug het, naamlik 46,5\% (261 van 561). Die media self het bykans een-vyfde (19,4\% (109 van 561)) van die klagteleggers uitgemaak deur middel van redaksionele kommentaar, rubrieke en artikels. Van die klagteleggers het politieke organisasies 12,8\% (72 van 561), kulturele organisasies $10,2 \%$ (57 van 561), en professionele organisasies $6,1 \%$ (34 van 561) uitgemaak.

Die Afrikaanse gedrukte media het die wydste mediadekking aan al die kategorieë van taalregteklagteleggers in die gedrukte media verleen. Die grootste verskil tussen die rapportering tussen die twee taalgroepe was $6,6 \%$ by die media self; en $5,9 \%$ vir private persone en $5,4 \%$ by politieke partye. Slegs by rapportering van taaIregteklagteleggers van professionele organisasies was die insidensie effens hoër $(1,7 \%)$ by die Engelse media. Alhoewel die Afrikaanse gedrukte media wyer dekking verleen het aan private klagteleggers, naamlik $26,2 \%$ (147), is die betekenisvolle insidensie van $20,3 \%$ (114) van die tradisionele Engelssprekendes hoofsaaklik toe te skryf aan negatiewe kommentaar na aanleiding van naamsveranderinge. 
Tabel 6: Taalregteklagteleggers per taalmedium

\begin{tabular}{|l|r|r|r|r|r|c|}
\hline & \multicolumn{2}{|c|}{ Afrikaans } & \multicolumn{2}{c|}{ Engels } & \multicolumn{2}{c|}{ Totaal } \\
\hline Klagteleggers & $\mathbf{N}$ & $\%$ & $\mathbf{N}$ & $\%$ & $\mathbf{N}$ & $\%$ \\
\hline Besigsheidsorganisasies & 4 & 0,7 & 4 & 0,7 & 8 & 1,4 \\
\hline Kulturele organisasies & 35 & 6,3 & 22 & 3,9 & 57 & 10,2 \\
\hline Regering (1ste, 2e, 3e vlak) & 3 & 0,5 & 2 & 0,4 & 5 & 0,9 \\
\hline Media & 73 & 13,0 & 36 & 6,4 & 109 & 19,4 \\
\hline Politieke organisasies & 51 & 9,1 & 21 & 3,7 & 72 & 12,8 \\
\hline Private persone & 147 & 26,2 & 114 & 20,3 & 261 & 46,5 \\
\hline Professionele organisasies & 12 & 2,2 & 22 & 3,9 & 34 & 6,1 \\
\hline Vakbonde & 7 & 1,2 & 2 & 0,4 & 9 & 1,6 \\
\hline Ander & 4 & 0,7 & 2 & 0,4 & 6 & 1,1 \\
\hline Totaal & $\mathbf{3 3 6}$ & $\mathbf{5 9 , 9}$ & $\mathbf{2 2 5}$ & $\mathbf{4 0 , 1}$ & $\mathbf{5 6 1}$ & $\mathbf{1 0 0 , 0}$ \\
\hline
\end{tabular}

Die oorgrote meerderheid kulturele organisasies, naamlik 50,9\% (29 van 57), het oor 'n wye verskeidenheid kulturele groeperings gestrek, byvoorbeeld Indiese drukgroepe, onder andere die SA Hindu Maha Sabha en die National Council of Eastern Languages $(14,0 \%$ (8 van 57$)$ ), die Nasionale Raad van Khoisan Opperhoofde, die Zoeloe Nasionale Taalraad, Grahamstown Residents' Association en die Alumni van die Noordwes-Universiteit (Potchefstroomkampus). Die oorgrote meerderheid Afrikaanse kulturele organisasies $(61,4 \%$ (35 van 57$)$ ) wat vir taalregteklagtes verantwoordelik was, was onder meer die Taalsekretariaat $(14,0 \%(8))$, Praag $(7,0 \%(4))$, die Federasie van die Afrikaanse Kultuurverenigings (FAK) $(5,3 \%(3))$, en die Groep van 63 (5,3\% (3)). Die politieke partye $(12,8 \%$ (72 van 561)) wat hoofsaaklik vir die taalregteklagtes verantwoordelik was, was die Demokratiese Party (DP) $(26,4 \%$ (19 van 72$))$, Nuwe Nasionale Party (NNP) $(26,4 \%$ (19 van 561)), en die Vryheidsfront (VF) met 22,2\% (16). Meer as die helfte, van die professionele organisasies, naamlik $52,9 \%$, was uit die geledere van die onderwys. Beheerliggame het ten minste eenvyfde van diesulkes uitgemaak $(23,5 \%(8))$, die Forum vir Multikulturele Parallelmedium Skole $(11,8 \%(4))$, Federasie van Beheerliggame Suid-Afrikaanse Skole $(14,7 \%$ (5)) en Suid- 
Afrikaanse Onderwysersunie (2,9\% (1)). Die klagtes was hoofsaaklik as gevolg van regeringspogings om die voertaal in skole te verander. Professionele organisasies buite die onderwys het omtrent 'n derde van die totaal uitgemaak, naamlik 29,4\% (10 van 34 ) en het onder meer Pretoria Chamber of Commerce, die NoordTransvaalse Pleknaamkomitee en die Getrouheidswaarborgfonds (GWF) ingesluit.

Ten einde die geldigheid van die gevolgtrekkings wat op grond van die empiriese ondersoek van rekords in die gedrukte media gemaak is te toets, word in die volgende afdeling die Pansatstudie as 'n kontrolestudie aangewend.

\section{Vergelyking met amptelike taalregteklagtes gerig aan Pansat}

Pansat vervul 'n sleutelrol om die implementering van ' $n$ taalbeleid in Suid-Afrika te verseker. Die doelwitte en bevoegdhede is in die PanSuid-Afrikaanse Taalraad Wet (Wet 59 van 1995) uiteengesit. Dit behels hoofsaaklik die bevordering van veeltaligheid, die verantwoordelikheid vir taalontwikkeling, navorsing oor taalbeleidsake, verskaffing van raad aan die regering oor taalbeleid, -wetgewing en -beplanningskwessies. Pansat tree ook op as bemiddelaar in gevalle van vermeende minagting van taalregte (cf. Marivate, 2000:132). Artikel 8 van Wet 59 van 1995 bepaal die bevoegdhede en werksaamhede van Pansat ten opsigte van taalregte. Afdeling 8(1)(i) bepaal Pansat

[K]an uit eie beweging of by ontvangs van 'n skriftelike klagte enige beweerde skending van 'n taalreg, taalbeleid of taalpraktyk ingevolge artikel 11 ondersoek.

Artikel 11 (Wet 59 van 1995) behandel die prosedure wat die Raad volg met betrekking tot arbitrasie, versoening en/of onderhandeling, en bepaal, inter alia dat

Enige persoon wat ten behoewe van homself of haarself optree of enige persoon, liggaam van persone of instelling wat ten behoewe van sy lede of lede van 'n taalgroep optree, of enige staatsorgaan kan 'n klagte betreffende enige beweerde skending of dreigende skending van ' $n$ taalreg, taalbeleid of taalpraktyk by die Raad indien.

Sedert 1997 was daar 'n volgehoue toename in die aantal taalregteklagtes wat by dié taalliggaam ingedien is. Dit het teen die einde van Maart 2002 'n rekordgetal van 234 taalregteklagtes bereik 
(Pansat, 2002:176). Hierna het die aantal taalregteklagtes betekenisvol tot 26 in 2003 gedaal. Taalregteklagtes was hoofsaaklik van die Afrikaanssprekende taalgroep afkomstig, naamlik 73\% (19 van 26 ) vir 2003. Daar is 'n betekenisvolle afname van $12 \%$ van die $85 \%$ taalregteklagtes deur Afrikaanssprekendes van 2002. Die aantal taalregteklagtes met betrekking tot inheemse tale, wat vermeerder het van $11 \%$ in $2000-2001$ tot $20 \%$ in 2001-2002 (Pansat, 2002:177), het met 19,3\% in 2003 geen noemenswaardige verandering getoon nie. Twee van die taalregteklagtes in 2003 het betrekking op Afrikatale in die algemeen, terwyl ' $n$ verdere twee onderskeidelik verwys het na Tswana en Ndebele.

In ooreenstemming met die neigings van 2002, het private persone weereens die meerderheid taalregteklagtes by Pansat aanhangig gemaak, naamlik 88,5\% (23 van 26). Die ander drie taalregteklagtes was afkomstig van twee politieke partye (NNP en VF) en die drukgroep, Praag.

Die oorgrote meerderheid $(69,2 \%)$ taalregteklagtes was aan Pansat gerig, soos ook die geval van klagtes wat in die media gerapporteer is as gevolg van taalmiskenning in regeringsdepartemente, spesifiek op eerste regeringsvlak. Die res van die klagtes, gerig teen nieamptelike organisasies, het 'n derde of $30,8 \%$ van die totaal behels.

Tabel 7 toon besonderhede aangaande die verspreiding tussen amptelike (eerste, tweede en derde vlak) en nie-amptelike instansies wat aanleiding gegee het tot taalregteklagtes wat by Pansat ingedien is.

Hiervolgens is dit duidelik dat die staat die bron van ten minste twee-derdes $(69,2 \%(18))$ van die amptelike taalregteklagtes is, met die eerstevlakregering (wat semi-staatsinstellings en statutêre liggame insluit) wat die grootste oortreder is, spesifiek die Kompensasiekommissie van die Departement van Arbeid wat geweier het om vorms in Afrikaans beskikbaar te stel. Die betekenisvolle toename wat gerig is teen nie-amptelike bronne, mag moontlik daarop dui dat nie-regeringsorganisasies die twyfelagtige voorbeeld van die staat volg in hul wyfeling om veeltaligheid te vestig/institutionaliseer. Hieronder ressorteer onder andere klagtes teen die Public Servants Association (PSA), Estate Board, Motornywerheidsbedingingsraad en Standard Bank. 
Tabel 7: Bronne wat aanleiding gegee het tot die registrasie van amptelike taalregteklagtes by Pansat

\begin{tabular}{|l|r|r|}
\hline \multicolumn{1}{|c|}{ Bronne } & N & \% \\
\hline Eerstevlakregering & 11 & 42,3 \\
\hline Tweedevlakregering & 2 & 7,7 \\
\hline Derdevlakregering & 5 & 19,2 \\
\hline Nie-amptelik & 8 & 30,8 \\
\hline Totaal & $\mathbf{2 6}$ & $\mathbf{1 0 0 , 0}$ \\
\hline
\end{tabular}

Tabel 8 tref 'n vergelyking tussen die bronne van insidente wat aanleiding gegee het tot briewe aan die pers en dié wat amptelik aan Pansat gerig is. Briewe is as vergelykingsmaatstaf geneem omdat dit (soos die taalregteklagtes aan Pansat) die gevoelens van individue weerspieël en dus as't ware 'n barometer van gesindhede is.

Tabel 8: Vergelyking tussen bronne van taalregteklagtes in briewe aan die pers en dié gerig aan Pansat

\begin{tabular}{|l|r|r|r|r|r|r|}
\hline & \multicolumn{2}{|c|}{ Briewe aan media } & \multicolumn{2}{c|}{ Pansat } & \multicolumn{2}{c|}{ Totaal } \\
\hline Bron & \multicolumn{1}{c|}{$\mathbf{N}$} & \multicolumn{1}{c|}{$\%$} & $\mathbf{N}$ & \multicolumn{1}{c|}{$\%$} & \multicolumn{1}{c|}{ N } & \multicolumn{1}{c|}{$\%$} \\
\hline Staat & 48 & 55,8 & 16 & 61,5 & 64 & 57,2 \\
\hline Semi-staat & 9 & 10,5 & 0 & 0,0 & 9 & 8,0 \\
\hline $\begin{array}{l}\text { Statutêre } \\
\text { liggaam }\end{array}$ & 7 & 8,1 & 2 & 7,7 & 9 & 8,0 \\
\hline Nie-amptelik & 22 & 25,6 & 8 & 30,8 & 30 & 26,8 \\
\hline Totaal & $\mathbf{8 6}$ & $\mathbf{7 6 , 8}$ & $\mathbf{2 6}$ & $\mathbf{2 3 , 2}$ & $\mathbf{1 1 2}$ & $\mathbf{1 0 0 , 0}$ \\
\hline
\end{tabular}

Behalwe die taalregteklagtes teenoor semi-staatsinstellings is daar 'n merkwaardige korrelasie van individuele klagtes gerig aan die redaksie van die koerant met dié aan Pansat. Dit is in teenstelling met bevindings van 2002, toe klagtes gerig aan Pansat teen 
staatsinstellings heelwat meer was as dié gelug in die pers. Taalregteklagtes teen private bronne in 2002 toon die teendeel: gedurende 2002 is $96,2 \%$ van die totale aantal klagtes in die media gelug, en net $3,8 \%$ was by Pansat geregistreer.

\section{Gevolgtrekking}

Die gedrukte media is toegerus om die belangrike rol te vervul om die ideologiese oriëntasie van vernakularisasie - die uitbouing van inheemse tale, in kontras met internasionalisme wat voorkeur verleen aan die nie-inheemse taal - te propageer. Hierdeur kan enersyds voorkom word dat die tien inheemse tale gemarginaliseer word, en andersyds word die voorkeur wat aan Engels verleen word, beperk.

Die Afrikaanse pers het, soos in die verlede, op die voorgrond getree om taalkwessies van al die inheemse tale in die algemeen en taalregteklagtes in die besonder, kundig te maak. Dit geld ook die wye mediadekking wat die taalgroep verleen aan (vermeende en werklike) taalregtemiskenning. So byvoorbeeld het die Afrikaanse media 27 meer verwysings na Pansat in sy beriggewing vir 2003 vervat (Tabel 1), dit is $72 \%$ (44 uit 61) teenoor die Engelse pers wat slegs $28 \%$ (17 uit 61 ) keer daarna verwys het. Aangesien sprekers van gemarginaliseerde Afrikatale in Suid-Afrika oorwegend die Engelse pers verkies, mag hierdie diskrepansie (mindere blootstelling in beriggewing van die taalliggaam) vir die toekoms nie noodwendig gunstig reflekteer op die beeld wat Pansat in die SuidAfrikaanse pers het nie.

Die skerp daling in taalregteklagtes wat gerig word aan Pansat (slegs 26 in 2003), toon 'n kommerwekkende erodering van vertroue in dié taalliggaam se vermoë om taalregteklagtes suksesvol op te los. Die relatiewe gemak van 'n beswaarde brief per e-pos aan die redakteur en die wyer mediadekking wat op so 'n wyse verkry word, het 'n verskuiwing van klagteleggers weg van dié taalligaam, wat dikwels 'n meer omslagtige oplossing van 'n taalregteprobleem het, met minder blootstelling in die media tot gevolg. Hierdie persepsie is waarskynlik die rede waarom politieke partye en kultuurgroepe minder amptelike klagtes tot Pansat gerig het en die oorgrote meerderheid taalregteklagtes (byna 90\% (23 uit 26)) van beswaarde individue afkomstig was.

Uit die ondersoek blyk dat die Afrikaanse perswese meer geneig is om die rol van "taalwaghond" te vervul en taalinsidente aan die groot klok te hang, en dat Pansat toenemend nie meer geraadpleeg word 
nie. Die taalinsidente wat hoofsaaklik aanleiding gegee het tot taalregteklagtes was hoofsaaklik rondom die voertaal in die onderwys. Die media het self, deur onder andere redaksionele kommentaar en privaat persone deur middel van briewe in die media, die publiek bewus gemaak van (vermeende en werklike) verwaarlosing van al die inheemse tale. Ten spyte van die wye dekking wat taalkwessies en taalregteklagtes in die gedrukte media geniet, is daar nie juis sprake van noemenswaardige regstellende handelinge van regeringsweë aan te toon nie.

Dit sal Pansat loon om 'n sterker samewerking tussen die Afrikaanse en Engelse media te bevorder ten behoewe van taalregte in Suid-Afrika. Aangesien sprekers van Afrikatale die Engelse media verkies, kan laasgenoemde aangespoor word om 'n sterker rol in die promovering van taalsake in die algemeen te vervul. Ten slotte, aangesien Pansat ondersoeke na taalregteskendings op eie inisiatief kan loods, kan dié taalliggaam daarby baat vind om die gedrukte media in ruimer mate as 'n bron vir moontlike ondersoeke aan te wend.

\section{Geraadpleegde bronne}

ANNUAL REPORT/REPORT ANNUEL. 2002. The texture of Canada/Le tissu social canadien. Office of the commissioner of official languages/ Commissariat aux langues officielles.

BOOYSEN, S. \& ERASMUS, E. 1998. Public policy making in South Africa. (In Venter, A., ed. Government and politics in the new South Africa. Pretoria: Van Schaik. p. 221-260.)

COBARRUBIAS, J. 1983. Ethical issues in status planning. (In Cobarrubias, J. \& Fishman, J.A., eds. Progress in language planning. New York: Mouton. p. 41-86.)

COULOMBE, P.A. 1993. Language rights, individual and communal. Language Problems and Language Planning, 17(2):140-152.

D'ALESSIO, D. \& ALLEN, M. 2000. Media bias in presidential elections: a metaanalysis. Journal of Communication:133-156.

DU PLESSIS, L.T. 1987. Die politiek van Standaard-Afrikaans - twee gevalle. Suid-Afrikaanse Tydskrif vir Taalkunde, 5(4):1-19.

DU PLESSIS, L.T. \& PRETORIUS, J.L. 2000. The structure of the official language clause: a framework for its implementation. South African Public Law, 15:505-526.

DU PLESSIS, THEO. 2004. Afrikaans en taalaktivisme. (In Van Rensburg, F.I.J., red. Afrikaans - lewende taal van miljoene. Pretoria: Van Schaik. p. 161-182.)

DU TOIT, Z.B. 2005. Ons soek aksie in Afrikaans. Beeld: 1, 3 Julie.

FOURIE, P. 1994. Zuid-Afrika. (In Van Zutphen, N. \& Nootens, J. Nederlandstalige en Afrikaanstalige media. 2e Internationale Colloquium Nederlands in de Wereld, Vlaamse Raad, Brussel, 24-26 Maart 1994. Brussel: VUBPRESS. p. 279-378.) 
GOOSEN, DANIE. 2005. Enkele voorwaardes vir 'n geloofwaardige antwoord op die onderwysvraagstuk. Die Vrye Afrikaan: 13-16, 4 Maart.

HORNBERGER, N.H. 2006. Frameworks and models in language policy and planning. (In Ricento, T., ed.. An introduction to language policy. Oxford: Blackwell. p. 24-41.)

JENKINS, R. 1991. Violence, language and politics: nationalism in Northern Ireland and Wales. North Atlantic Studies, 3(1):31-40.

KAMWANGAMALU, N. 2003. Language and education in Africa: emanicipation or alienation. (In Cuvelier, P., Du Plessis, T. \& Teck, L., eds. Multilingualism, education and social integration. Pretoria: Van Schaik. p. 175-184.)

LUBBE, H.J. 2003. Ideologie en meertalige onderwysbeleid. Tydskrif vir Christelike Wetenskap, 39(1 \& 2):115-136.

LUBBE, H.J. \& DU PLESSIS, L.T. 2001. Die debat rondom die vertolking van die amptelike taalbleidsbeginsels van die Oorgangsgrondwet in die gedrukte media: 'n inhoudsontleding. Southern African Linguistics and Applied Language Studies, 19:12-41.

MARIVATE, C. 2000. The mission and activities of the Pan South African Language Board. (In Deprez, K. \& Du Plessis, T., eds. Multilingualism and government. Pretoria: Van Schaik. p. 130-137.)

MARTEL, A. 1999. Heroes, rebels, communities and states in language rights activism and litigation. (In Kontra, M., Phillipson, R., Skutnabb-Kangas, T. \& Varady, T., eds. Language: a right and a resource. Budapest: Central European University Press. p. 47-80.)

PANSAT. 2001. Pan South African Language Board: annual report 2000/2001. Arcadia: PanSALB.

PANSAT. 2002. Pan South African Language Board: annual report 2001/2002. Arcadia: PanSALB.

SALRM

see SOUTH AFRICAN LANGUAGE RIGHTS MONITOR.

SCHLEMMER, L. \& GILIOMEE, H. 2001. Oorsig en gevolgtrekkings. (In Giliomee, H. \& Schlemmer. L., reds., Alexander, N., Du Plessis, B. \& Loubser, M. Kruispad. Kaapstad: Tafelberg. p. 115-135.)

SOUTH AFRICAN LANGUAGE RIGHTS MONITOR. 2004. First Report on the South African Language Rights Monitor Project, 1 January 2002-31 December 2002. Bloemfontein: Unit for Language Facilitation and Empowerment, University of the Free State.

SOUTH AFRICAN LANGUAGE RIGHTS MONITOR. 2005. Second report on the South African Language Rights Monitor Project, 1January 2003-31 December 2003. Bloemfontein: Unit for Language Facilitation and Empowerment, University of the Free State.

STEYN, J.C. 1980. Tuiste in eie taal. Kaapstad: Tafelberg.

STEYN, J.C. 1995. Die taalstryd in die oorgangstyd - gesindhede teenoor Afrikaans 1990-1994. Stilet Supplement, 1:1-150.

STEYN, JAAP. 2005. Protes moet sterker. Volksblad: 10, 13 Julie.

STRYDOM, H. \& PRETORIUS, L. 2000. On the directives concerning language in the South African Constitution. (In Deprez, K. \& Du Plessis, T. Multilingualism and government. Pretoria: Van Schaik. p. 111-120.)

THETELA, P. 2001. Critique discourses and ideology in newspaper reports: a discourse analysis of the South African press reports on the 1998 SADC's military intervention in Lesotho. Discourse and Society, 12(3):347-370. 
TOLLEFSON, J.W. 1991. Planning language, planning inequality. London: Longman.

TRUTER, E.J.J. 2002. Ontleding van die reaksies van die Afrikaanssprekende op taalmiskenning in die Vrystaat vir die periode 1994-1998. South African Linguistics and Applied Language Studies, 20:283-302.

TRUTER, E.J.J. 2003. 'n Ontleding van die reaksies in die media op die taalbesluite van die SAUK, 1994-1996. Acta Academica Supplementum, 2003(2):32-57.

TRUTER, E.J.J. \& LUBBE, H.J. 2005. Toepassing van die taalbeleid in SuidAfrika: 'n ontleding aan die hand van taalregteklagtes van minderheidsgroepe. Tydskrif vir Geesteswetenskappe, 45(2):264-263.

VAN RENSBURG, F.I.J., red., MALHERBE, E.F.J. \& LANDMAN, K.J.H. s.a. Taalverskuiwing sedert 1994: die prosesse van bevoorregting, ontmagtiging en verwaarlosing. s.l.: sn.

\section{Kernbegrippe:}

gedrukte media: empiriese ondersoek

Pansat

Taalregte

Key concepts:

language rights

PanSALB

printed media: empirical investigation 